\title{
TWO LOST SONNETS BY STERLING A. BROWN
}

\author{
edited and introduced by John Edgar Tidwell and Ted Genoways
}

The emergence of Sterling A. Brown into poetic maturity resulted from a wellknown dialectical engagement with the aesthetics of African-American folk tradition. As Brown recounted so often, these experiential and imaginative encounters derived from a benevolent conspiracy between his theologian father, the Rev. Sterling Nelson Brown, and the eminent historian Carter G. Woodson to send the younger Brown South, to learn something about his people. Socially, this meant that at Virginia College and Seminary (1923-1926), before moving on to Lincoln University (19261928) and Fisk University (1928-1929), Sterling A. Brown began divesting himself of the confining Black middle-class ethos of Washington, D.C., and of a New EnglandIvy League sensibility instilled by formal education at Williams College (1918-1922) and Harvard University (1922-1923). Aesthetically, the move South meant an enthusiastic immersion into and embrace of the Black South, especially its folk life, language, and lore-a relationship from which would come his best-known work. Lost, or at least understated, in this pursuit of a folk-based metaphysic is his point of departure.

Brown's quest for a distinctive, engaging poetic voice began, as it did for most writers, with the self. According to archival sources containing his "apprentice" work, the young Brown was thoroughly steeped in late 19th-century Victorian poetry. For example, many of these early experiments clearly show an effort to gain formal mastery of the ballad, villanelle, ballade, hymn, and sonnet. Conceptually, Brown located his vision in an aesthetic that critic David Perkins, in another context, calls "the nineteenth century convention of personal utterance" ( $A$ History of Modern Poetry $5)$. By developing themes of unrequited love, anger, self-recrimination, beauty, and self-doubt, he focused much of this early work on feelings, as if the very cultivation of emotion was poetry's raison d'etre. These and other Brown poems self-consciously courted "racelessness," symbolic expression, and the romantic excess that places emotion on a poetic pedestal. Although Brown preserved the best of these early poems in the "Vestiges" section of Southern Road and the "Remembrances" section of No Hiding Place, other poems reveal much about Brown's developing proficiency.

Of these apprentice works, two poems-both sonnets-published by Brown during his lifetime remain uncollected: "For a Certain Youngster," published in The Oracle in March 1925, and "After the Storm," published in The Crisis in April 1927 (see Robert G. O'Meally's revised bibliography in this issue for full citations). Many other poems written by Brown during this same period of time remain tucked away in his notebooks, unpublished at Brown's own request. The two poems presented here then 
are merely representative and not meant as a complete record of his early work. They have been selected for publication because they are already available to any reader with the patience to search them out, because they are the only poems from these early trial pieces that contemporary editors thought worthy of publication, and because they contain elements of Brown's future genius which bear critical scrutiny. These poems above all else provide a context for the stylistic tectonic shift Brown would undergo.

The first issue that must be addressed is the question of the composition date of these poems-both relative to each other and to Brown's other work. Both sonnets appeared in the middle 1920s; however, examination of Brown's manuscript notebooks indicates they were composed years prior to their publication. And, although "After the Storm" was published two years later than "To a Certain Youngster," the notebook draft of "After the Storm" appears in an earlier entry, dated Spring 1921. (It appears in the same notebook as the later, undated "A Youngster to Young Men" that would eventually become "To a Certain Youngster.") This must be remembered, because the delay between acceptance and publication varied from magazine to magazine, often obscuring the chronology of composition. "After the Storm," for example, appeared in print roughly contemporary to much of the work later gathered in Southern Road, but it was composed at least six years prior to many of those poems. Indeed, both "After the Storm" and "To a Certain Youngster" must be considered products of a writer just entering his twenties, still experimenting with the limitations and freedoms of rhyme and meter.

Even without the assistance of Brown's careful manuscripts, "After the Storm" would be immediately recognizable as the work of a young poet. Written in a stilted, nearly Victorian diction, the poem is a strict Italian sonnet, employing only tight rhymes and occasionally indulging "poetic" contractions in order to adhere to iambic pentameter. The resulting poem is generally weak, and when it appeared in The Crisis in 1927, it was without Brown's consent or knowledge. When he received his copy, Brown wrote directly to the editor W.E.B. DuBois. In a letter dated March 28, 1927, now in the DuBois Papers at the University of Massachusetts, Brown wrote:

I have at hand a copy of the April Crisis in which I see included a poem of mine, After the Storm [sic]. I am properly thankful that you thought it worth publishing, but I am in the dark as to how it got into your hands. I hope you will understand the spirit in which this is written. I did not expect to see it, and still do not quite understand the publishing of it. That bit of mystery I am writing you to clear up for me. Would you send me the source from which you got it?

He never received an adequate explanation of how DuBois acquired his early poem, but Brown's displeasure is not hard to understand. By April 1927, he had published seven poems that would later appear in Southern Road. Among those, "Challenge," "Odyssey of Big Boy," "Return," "Salutamus," and "To a Certain Lady, in Her Garden" had been presented as a group in the prestigious Caroling Dusk, edited by 
Countee Cullen. Still more recent poems had been accepted elsewhere, including Brown's quintessential "When de Saints Go Ma'ching Home," which was scheduled to appear that summer in Opportunity as the winner of their annual poetry prize. By the time "After the Storm" appeared in The Crisis, the poem was long-forgotten to Brown and was, by any critical estimation, the product of a much earlier stage of development.

Nevertheless, "After the Storm" does reveal one essential characteristic that runs throughout Brown's best work. The turn that begins the poem's second stanza moves from the abstract, objectified landscape to a more specified, human experience. The shift echoes the way many of his later poems turn from comedy, or occasionally nostalgia, to issues of immediate, even political, concern. In particular, race and art appear here for the first time in Brown's work. Stripped of its serpentine sentence structure, the central statement of the closing sestet is: "Tis like that heart.../ which. ... / has fitly learned / To stifle throes of pain, has ne'er rebelled / In angry bitterness, has merely turned / Gayness to pathos, with no beauty lost." The language is not Brown's, but the stunning juxtaposition and the conviction with which it is made are unmistakable.

Early assays like "After the Storm" also helped bolster Brown's increasing confidence as a poet, allowing him to explore further-testing both the demands of language and the strictures of form. "For a Certain Youngster" is one tangible product of such experimentation. The language is still occasionally ham-strung by poeticisms ("undue remorses") and clichés ("the blistering sun"); however, the voice has been transformed from proper and timid to forceful and sardonic. Moreover, the strict iambic pentameter has been shed in favor of an accentual meter; each line contains five accents, but the syllable count varies from nine to twelve. The rhyme scheme is an invented hybrid of the Italian and English form, following an ababbaba cdcdee pattern. Equally important is the variation of the third $a$-rhyme, "upon." By loosening the rhyme slightly at that point, Brown mirrors the shift in voice in the poem. The lines become more heavily enjambed, the rhyme moves to the background, and for a span of several lines, the poet hints at the muscular combination of voice and rhythm that will be fully developed in later poems.

The poem printed here is taken from the version published in 1925 in The Oracle, the official publication of Brown's fraternity, Omega Psi Phi. The early notebook draft, titled "A Youngster to Young Men," differs little from the published version, with the notable exception of the final couplet. The draft version reads: "Were there no power forbidding us to quail / Haughtily ignorant of the words, we fail." The fact that this appears to be the only significant revision to the poem highlights the trouble Brown experienced with this final couplet. Powerful as the previous four lines are (especially the decidedly Brown-esque "to the hog level"), they rhetorically force him to condemn rebellion. Brown obviously struggled with ways to word his final couplet, searching for language that would be palatable both to himself and to his readers.

Appropriately, it is the very word "rebel" that these two early sonnets have in common. Brown's earliest rebellions against conventional forms, both poetic and social, are preserved vividly in these poems; we see a young man wrestling with the political issues that would define his work and his times. And as the historical record 
shows, the word "rebel" applies equally to Brown's personal need to define himself free not only from Victorian conventions of poetry but also from the encumbrance of "school" or "movement" that, in his view, robbed the poet of individuality, of aesthetic uniqueness. Arguably, one of the most compelling statements of this quest can be found in his application which won for him a Guggenheim Fellowship for 1937. Brown wrote:

I became ambitious to write while in college. My first years out of college were spent in Virginia; here I tried to learn as much as I could about folkways and folkspeech. These were the years of the so-called Negro Renaissance, and the Harlem school of writing. In contrast to the Harlem school I wanted to interpret the Negro of the South, who has been much dealt with by white authors, but only infrequently by Negroes. I therefore spent a great deal of time living with the folk and attempting to get as much of the truth as I could about them.

By 1937, then, Brown's quest in pursuit of voice was complete. The journey that had begun haltingly in the style of Victorian England successfully concluded-in the lives, the lore, and the language of the Black South. 